\title{
Impact of a tsunami generated at the Lesser Antilles subduction zone on the Northern Atlantic Ocean coastlines
}

\author{
J. Roger ${ }^{1, *}$, A. Frère ${ }^{2,3}$, and H. Hébert ${ }^{2}$ \\ ${ }^{1}$ Université des Antilles et de la Guyane, Laboratoire LaRGe, 97157 Pointe à Pitre Cedex, Guadeloupe (FWI) \\ ${ }^{2}$ CEA/DAM/DIF, 91297 Arpajon, France \\ ${ }^{3}$ Institut de Physique du Globe de Paris, 75007, Paris, France \\ *now at: GMER Etudes Marines, Avenue de l'Europe, 97118 Saint-François, Guadeloupe (FWI)
}

Correspondence to: J. Roger (jeanrog@ @otmail.fr)

Received: 18 December 2013 - Revised: 3 June 2014 - Accepted: 10 June 2014 - Published: 25 July 2014

\begin{abstract}
On 11 March 2011, a $M_{\mathrm{w}} \sim 9.0$ megathrust earthquake occurred off the coast of Tohoku, triggering a catastrophic tsunami reaching heights of $10 \mathrm{~m}$ and more in some places and resulting in lots of casualties and destructions. It is one of a handful of catastrophic tsunamis having occurred during the last decade, following the 2004 Indonesian tsunami, and leading to the preparation of tsunami warning systems and evacuation plans all around the world. In the Atlantic Ocean, which has been struck by two certified transoceanic tsunamis over the past centuries (the 1755 "Lisbon" and 1929 Grand Banks events), a warning system is also under discussion, especially for what concerns potential tsunamigenic sources off Iberian Peninsula. In addition, the Lesser Antilles subduction zone is also potentially able to generate powerful megathrust ruptures as the 8 February $1843 M_{\mathrm{w}} \sim 8.0 / 8.5$ earthquake, that could trigger devastating tsunamis propagating across the Northern Atlantic Ocean. The question is in which conditions these tsunamis could be able to reach the Oceanic Islands as well as the eastern shores of the Atlantic Ocean, and what could be the estimated times to react and wave heights to expect? This paper attempts to answer those questions through the use of numerical modelings and recent research results about the Lesser Antilles ability to produce megathrust earthquakes.
\end{abstract}

\section{Introduction}

\subsection{Generalities}

The Atlantic Ocean, a low rate expanding ocean (the average spreading rate of the mid-ocean ridge is estimated around $2.5 \mathrm{~cm} \mathrm{yr}^{-1}$ ), is not bordered by a fire belt like the Pacific Ocean, but shows however some particular places to monitor and able to trigger some catastrophic tsunamis according to available tsunami databases (Gusiakov and Mercado, 2002; Lander et al., 2002; Baptista and Miranda, 2009; Baptista et al., 2011; NGDC, 2013) and geological settings. These tsunami generating zones are split in two parts: in one hand, the active zones, represented by convergent plate boundaries: the Antilles subduction zone for the western side of the Atlantic, which generated several local or regional tsunamis as for example the 1867 Virgin Islands event (Zahibo et al., 2003; Barkan and ten Brink, 2010), and the Iberian Peninsula fault system for the eastern side, especially known because of the 1755 "Lisbon" tsunami, which was historically recorded at lots of locations in the Northern Atlantic Ocean including the Lesser Antilles (Barkan et al., 2009; Roger et al., 2010a, b, c). On the other hand passive zones like the Northeastern American margin experienced intraplate earthquakes and margin destabilizations leading to landslides triggering tsunamis (Driscoll et al., 2000; Twichell et al., 2009; Tappin, 2010). As an example, the 1929 Grand Banks $M_{\mathrm{w}} \sim 7.2$ earthquake was followed by a transoceanic tsunami recorded further at Portuguese coastal tide gages (Fine et al., 2005; Ruffman and Hann, 2006), related afterward to a submarine landslide triggered by the seismic shaking. In the passive zones are also included oceanic hot spots highlighted 
by active volcanism (Azores, Canaries Archipelago, Iceland) and potentially able to collapse and produce catastrophic tsunamis as the Cumbre Vieja volcano (Ward and Day, 2001) or the active slump of Pico Island, Azores (Hildebrand et al., 2012).

\subsection{The Antilles subduction zone}

The boundary between the North Atlantic and the Caribbean tectonic plates is the only active subduction zone of the Atlantic Ocean extending from the Barbados prism in the South, to Cuba in the North, underlined by active volcanism and moderate to high seismicity (with magnitudes $M_{\mathrm{w}}>$ 7.0). This southwestward-dipping subduction of the North Atlantic plate under the Caribbean plate shows a compression rate of about $18-20 \mathrm{~mm} \mathrm{yr}^{-1}$ (DeMets et al., 2000). This subduction zone is divided in two distinct parts separated by the Anegada Passage: the Greater Antilles subduction zone, lying north of the Passage, including Hispaniola, Puerto Rico and the Virgin Islands, and the Lesser Antilles subduction zone, from the Virgin Islands to the north coast of South America (offshore Trinidad) through the Barbados accretionary prism (Fig. 1). The Greater Antilles and the northern part of the Lesser Antilles subduction zone is particularly interesting as it is more active in terms of seismicity rate than the southern part of the Lesser Antilles zone (the southern part, south of Martinique Island, represents the instrumentally aseismic Barbados prism), probably because of the interaction between the aseismic ridges and the subduction interface (McCann and Sykes, 1984). For information, the Greater Antilles subduction zone appears to be historically more prone to big earthquakes triggering catastrophic tsunamis as the 1918 Puerto Rico event with reported runup heights of $6 \mathrm{~m}$ and more (Mercado and McCann, 1998). Being part of tsunami hazard assessment for US territories, Grilli et al. (2010) propose some tsunami simulations concerning particularly a $M_{\mathrm{W}}=9.1$ megathrust earthquake and its possible impact on nearby Puerto Rico and on the US East Coast.

Furthermore, the Lesser Antilles subduction is interesting in two points: firstly, as indicated by Müller and Landgrebe (2012), it represents a good candidate to strong seismic coupling and so, to great earthquake supercycles. The authors explain in details the role of subducting fracture zone ridges in that process as previously discussed by Kodaira et al. (2003) indicating a kind of locking of these ridges leading to a strain accumulation able to trigger megathrust earthquakes. But, as the seismic knowledge of the Caribbean region is relatively new in comparison to other active zones of the world like the Japanese trench or the Mediterranean Sea for example, the lack of big earthquakes reported during the last 500 years is probably the main reason leading to hasty conclusions about the non-capacity of the Antilles subduction zone to produce megathrust earthquakes of $M_{\mathrm{W}}=7.0$ and more (see Murty et al., 2005, for example). In fact the last earthquakes (that



Figure 1. (a) Travel times of a tsunami (TTT) triggered by an earthquake occuring at the Lesser Antilles subduction interface and travelling across the Northern Atlantic Ocean. Shadded bathymetry has been added to underline the role played by submarine features over tsunami propagation. The geographical boundaries of the calculation grids are located. (b) General tectonic setings of the Lesser Antilles Arc: the solid black line with triangles locates the accretionnary prism frontal thrust (Feuillet et al., 2011a). Both megathrust earthquake estimated epicenters from 8 February $1843\left(M_{\mathrm{W}} \sim 8.0\right.$ $8.5)$ and 11 January $1839\left(M_{\mathrm{W}} \sim 7.5-8.0\right)$ are symbolized by red stars. The compression rate and direction indicated by a black arrow is from DeMets et al. (2000).

have been recently named megathrust events by Feuillet et al., 2011a) exhibited go back to 11 January $1839\left(M_{\mathrm{w}} \sim 7.3\right)$ and 8 February $1843\left(M_{\mathrm{w}} \sim 8.0 / 8.5\right)$ and these events are not historically known to have been followed by destructive tsunamis (Feuillet et al., 2011a; Roger et al., 2013). Notice that this subduction zone is also the theater of nonthrust events like the $1974 M_{\mathrm{S}}=7.6$ (McCann et al., 1982) or more recently the 18 February $2014 M_{\mathrm{W}} \sim 6.5$ normalfault earthquakes. Sometimes these earthquakes are able to trigger directly or indirectly some local or regional tsunamis as the 2004 Les Saintes $M_{\mathrm{w}}=6.3$ earthquake (Le Friant et al., 2008; Feuillet et al., 2011b). In addition, the recent and catastrophic 2011 Tohoku event in Japan also leads to ask in what conditions this subduction zone is able to generate a huge tsunami and if so, what could be the impact locally, but also more generally along the whole Northern Atlantic coastlines?

The second point is that the Lesser Antilles subduction trench faces the Atlantic Ocean, and more particularly Western Europe and its overseas satellites (Azores, Madeira and Canarias Archipelagos) which have been severely impacted by the 1755 "Lisbon" tsunami. Thus, tsunami generation scenarios in this region should be considered for tsunami hazard assessment plans for Atlantic coastal communities as France, Portugal, Morocco, Mauritania, Senegal, etc. even if their coastlines seem to be geographically and/or historically not inclined to tsunami waves. As an example, recent studies of the 1755 earthquake off Portugal and of its 
associated tsunami, highlighted the fact that, despite its apparently well protected location in relation to the tsunami source, the French western coastline, and especially the surroundings of La Rochelle, could have been subject to tsunami wave arrivals, as evidenced from several numerical modelings: according to these modelings, the nearby islands of Ré and Oléron could have exhibited maximum wave heights (MWH) of $50-100 \mathrm{~cm}$ on their western shores for most of the 1755 tested scenarios (Allgeyer et al., 2012). In the frame of the establishment of tsunami warning systems in the Caribbean and the Northeast Atlantic and Mediterranean regions, the assessment of tsunami hazard for the exposed coastlines is the most important task. The case of scenarios triggered in one region with effects in another region is also of particular interest in order to improve communication procedures between operational systems.

\subsection{Objectives of this paper}

This paper aims to discuss about the potential of tsunami generation of the Lesser Antilles subduction zone and what would be the impact of a transoceanic event across the Atlantic ocean. A special focus on the French coast related to a 1843-like scenario is also presented and discussed.

\section{Numerical modeling}

\subsection{Methodology}

The numerical code used for tsunami modeling has been developed by the French Commissariat à l'Energie Atomique (CEA) (Guibourg et al., 1997). It is used to model the initiation of the tsunami wave, and then, to compute its propagation over bathymetric grids solving the non linear shallow water long-wave equations, derived from Navier-Stokes equations. The initial deformation is computed through an elastic dislocation model based on the formulas established by Okada (1985). This deformation is considered to be transmitted without losses to the entire water column above. Tsunami propagation is obtained solving the hydrodynamic equations of continuity (1) and momentum (2) in spherical coordinates using a Crank-Nicholson finite difference method, centered in time, with an upwind scheme in space,

$$
\begin{aligned}
& \frac{\partial(\eta+h)}{\partial t}+\nabla[\boldsymbol{v}(\eta+h)]=0, \\
& \frac{\partial(\boldsymbol{v})}{\partial t}+(\boldsymbol{v} \nabla) \boldsymbol{v}=-g \nabla \eta+\sum f,
\end{aligned}
$$

where $h$ is the water depth, $\eta$ the water elevation above mean sea level, $\boldsymbol{v}$ the horizontal velocity vector averaged along the depth and $g$ the gravity acceleration constant. For this computation, both the bottom friction and Coriolis forces are neglected $\left(\sum f\right)$. In both Eqs. (1) and (2), the non-linear terms are taken into account in each point of the model. This method has been proved successful in previous studies in the Mediterranean or the Atlantic Ocean especially for historical tsunamis (see for example Roger et al., 2010a, 2011; Allgeyer et al., 2012).

The tsunami propagation velocity changes with the depth $h$, following the law $c=\sqrt{g h}$. When getting close to the coast, and thus to shallower water depths, the tsunami wave train slows down. Since the finite difference method uses a constant spatial increment over the whole grid, several nested grids are needed with an increased resolution to simulate properly the coastal shoaling effect.

\subsection{Input data}

The grids for the northern Atlantic Ocean and the French Coastline (grids 0, 1, 2, 3, 4, and 5; Figs. 1 and 2) were generated using the GEBCO $1^{\prime}$ World Bathymetric Grid (IOCBODC 1997). The main grid (0) has been resampled to $5^{\prime}$ which is enough to model correctly the far-field propagation of such tsunamis triggered by large earthquakes (teletsunamis). The subgrids have been defined for numerical stability and depending on the coastal targets, for the Azores region, for the northeastern margin of South America, for the Western African margin and the French western coastline:

- subgrids for the northeastern margin of South America (grid 1), the Azores (grid 2), the Cape Verde archipelago (grid 3) and Western Africa, including the Canaries Islands (grid 4), have been prepared from the GEBCO dataset sampled at $2^{\prime}(\sim 3700 \mathrm{~m})$ (Fig. 2);

- in order to model correctly the tsunami arrival on the French western coastline, subgrids are sampled at a resolution of respectively $1^{\prime}$ (grid 5) and $15^{\prime \prime}$ (grid 6) to approach the margin (Fig. 2a). A subgrid with a $3^{\prime \prime}$ ( $\sim 90 \mathrm{~m}$, grid 7$)$, resolution shows the region near the town of la Rochelle, focusing on the islands of Ré and Oléron. Further subgrids shown on Fig. $2 b$ focus on the town of la Rochelle with respective resolutions of $30 \mathrm{~m}$ (grid 8) and $10 \mathrm{~m}$ (grid 9) representing the trade port (Allgeyer et al., 2012). These 4 grids are integrated in grid 0 and were also prepared using GEBCO data, supplemented with single-beam bathymetric data from the French SHOM (French Hydrographic Service). The grids were interpolated using the inverse distance weighting method, and considering the mean sea level as a reference of wave height. The grids and the associated modeling results do not take into account the important coastline changes that have taken place between the 18th and 19th centuries, especially in France, as we used present elevation data.

The time step used to solve the hydrodynamic Eqs. (1) and (2) decreases when the grid spatial step decreases, and respects for each grid level the CFL criterion to ensure numerical stability (Courant et al., 1928). 


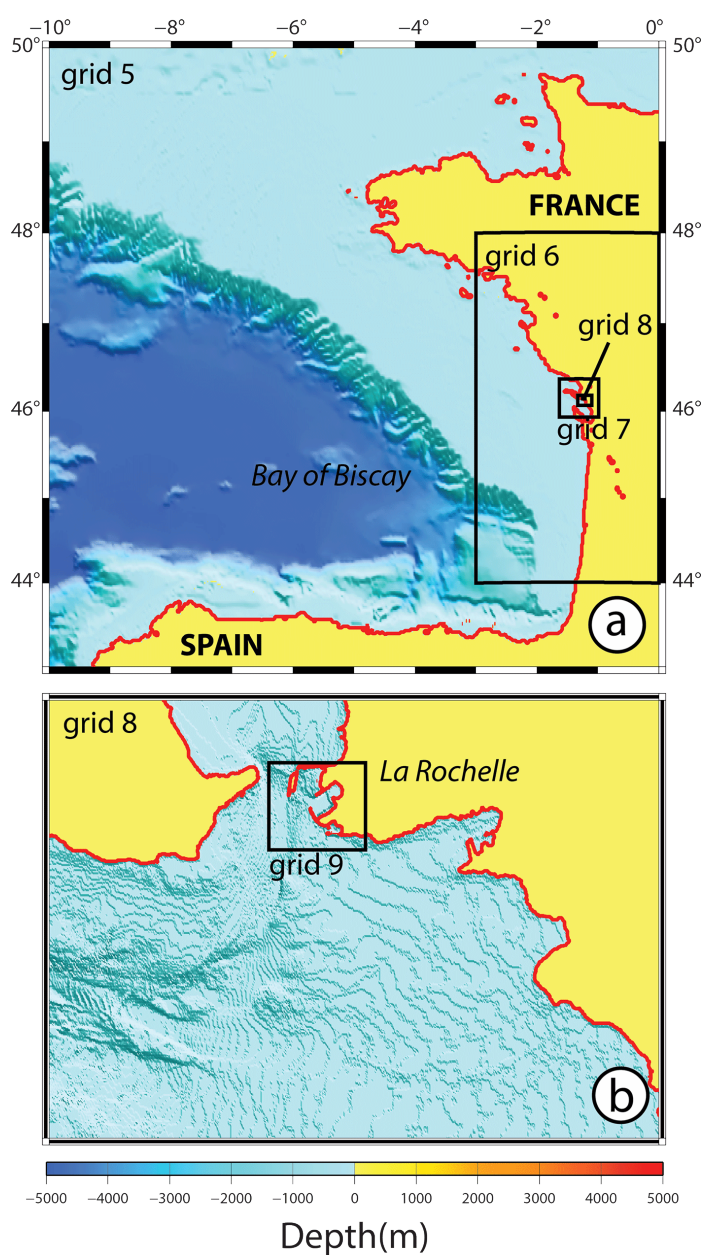

Figure 2. Geographical location and extension of subgrids 5-9: (a) in the Bay of Biscay and (b) focus on la Rochelle Trade Port.

\subsection{Tsunami generation scenarios}

For the purpose of this study, numerical tests have been performed corresponding to several cases of tsunami generation by $M_{\mathrm{w}} \sim 8.4$ earthquakes occurring along the Lesser Antilles subduction interface. This magnitude value, set within the range of the estimated maximum of $8.0<M_{\mathrm{Wmax}}<8.5$, and the corresponding fault plane parameters have been chosen following the recent studies of Feuillet et al. (2011a), Roger et al. (2013), and Hayes et al. (2013) about the 8 February 1843 Lesser Antilles earthquake, and in agreement with used dataset and empirical relations obtained by Strasser et al. (2010), Blaser et al. (2010), and Murotani et al. (2013). For information, a $M_{\mathrm{w}} \sim 8.4$ earthquake corresponds approximately to a moment magnitude $\left(M_{0}\right)$ of $6 \times 10^{21} \mathrm{~N} \mathrm{~m}$ according to the relation $M_{\mathrm{w}}=\frac{2}{3} \log \left(M_{0}\right)-6.0$ (Hanks and Kanamori, 1979) leading to a maximum rupture area of $\sim 4 \times 10^{4} \mathrm{~km}^{2}$ and a maximum rupture slip of $5 \mathrm{~m}$ conforming to these relations. The rigidity coefficient has been chosen according to the study of Bilek and Lay (1999) about the rigidity variations with depth in subduction zones. Only three of the tested scenarios are detailed in Table 1 and the related modeling results shown in this paper; in line with the objectives of this study they are sufficient to understand what could happen if a tsunami was generated in the Lesser Antilles and travelled across the Atlantic Ocean. However they represent worst case scenarios, especially with respect to recent reappraisals of the 1843 earthquake (Beauducel and Feuillet, 2012), which may be associated to a deep rupture, i.e. at the subduction interface, but for which no tsunami observation has been clearly reported unlike for the oldest 1755 tsunami.

\section{Results}

\subsection{Northern Atlantic impact}

There are two types of modeling results. The main important information related to tsunami modeling and useful for tsunami warning plans are the tsunami travel times (TTT) calculated from the source area to specific coastal places. In this case of a Lesser Antilles tsunami propagating across the Northern Atlantic Ocean, TTT calculations show on Fig. 1 indicate that in each tested case, the first wave should strike firstly the northeastern coast of South America within approximately $2 \mathrm{~h}$, impacting the Cape Verde Archipelago $3 \mathrm{~h}$ after (after $\sim 5 \mathrm{~h}$ of tsunami propagation), closely followed several minutes later by the Azores Archipelago, then by the Eastern African margin from Senegal to Morocco $(\sim 6 \mathrm{~h})$ and finally by Portugal $(\sim 7 \mathrm{~h})$, Southern Spain and France after $8 \mathrm{~h}$ of propagation. The second important information concerns the predicted wave heights reached in coastal areas: the maximum wave height (MWH) maps of the 3 scenarios detailed in Table 1, calculated over the $5^{\prime}$ resolution grid (grid 0) covering the Northern Atlantic Ocean and corresponding to $12 \mathrm{~h}$ of tsunami propagation show that in each presented case (Fig. 3), the bathymetric features (mid-ocean ridge, transform faults, oceanic basins, etc.) plays a predominant role on wave propagation and amplification behavior focusing the tsunami energy and/or defocusing it onto specific targets like the Western African margin or the Azores Archipelago as previously shown by lots of authors like Satake (1988) for historical tsunamis in other oceans and theoretically well-explained by Berry (2007). The role of the source's strike is also clearly demonstrated on Fig. 3, the main energy lobe being perpendicular to the fault direction (note that the slip angle (rake) plays also a predominant role on the lobe direction but stays unchanged in that study).

\subsection{Azores}

Figure 3 highlights the fact that the Azores Archipelago, located at the triple point between the Atlantic mid-ocean ridge and the Gloria transform fault, acts like a shield, diffracting the incoming waves, providing an apparent protection to France from waves coming from the Caribbean, resulting 
Table 1. Parameters corresponding to the three scenarios of $M_{\mathrm{W}} \sim 8.4$ earthquakes located along the Lesser Antilles subduction zone.

\begin{tabular}{lllllllllll}
\hline Source & $\begin{array}{l}\text { Lon } \\
\left(^{\circ}\right)\end{array}$ & $\begin{array}{l}\text { Lat } \\
\left(^{\circ}\right)\end{array}$ & $\begin{array}{l}\text { Depth of the fault } \\
\text { plane center } \\
(\mathrm{km})\end{array}$ & $\begin{array}{l}\text { slip } \\
(\mathrm{m})\end{array}$ & $\begin{array}{l}\text { strike } \\
\left(^{\circ}\right)\end{array}$ & $\begin{array}{l}\text { dip } \\
\left(^{\circ}\right)\end{array}$ & $\begin{array}{l}\text { rake } \\
\left(^{\circ}\right)\end{array}$ & $\begin{array}{l}\text { length } \\
(\mathrm{km})\end{array}$ & $\begin{array}{l}\text { width } \\
(\mathrm{km})\end{array}$ & $\begin{array}{l}\text { rigidity } \\
\left(\mathrm{N} \mathrm{m}^{-2}\right)\end{array}$ \\
\hline 1 & -60.4 & 15.1 & 35 & 5 & 165 & 26 & 90 & 400 & 100 & $30 \times 10^{9}$ \\
2 & -61.3 & 16.8 & 35 & 5 & 145 & 26 & 90 & 400 & 100 & $30 \times 10^{9}$ \\
3 & -62.3 & 17.8 & 35 & 5 & 120 & 26 & 90 & 400 & 100 & $30 \times 10^{9}$ \\
\hline
\end{tabular}



Figure 3. Maximum wave height maps over the Atlantic Ocean, after $12 \mathrm{~h}$ of tsunami propagation, for 3 different locations and strikes of a rupture scenario of magnitude $M_{\mathrm{W}} \sim 8.4$. (a), (b), and (c) correspond respectively to scenarios 1,2 , and 3 in Table 1 .

for the 1843-like scenario (no. 2), in a reduction of offshore MWH from $70 \mathrm{~cm}$ before the promontory, to $30-40 \mathrm{~cm}$ after it (Fig. 4) and to coastal wave heights of less than $50 \mathrm{~cm}$ in France (Figs. 5 and 7). In comparison, these maps show that other coastlines, as those of Portugal or Africa are not as well protected (MWH of more than $50 \mathrm{~cm}$ ).

\subsection{Cape Verde and Northwestern Africa}

Figure 3 is also interesting for the western coast of Africa since it clearly reveals that the most restrictive scenario for Africa (i.e. no. 1) does not have the worst consequences on the coastline except for the Cape Verde Archipelago, in comparison with scenario 2 especially off the coast of South Morocco where the margin exhibits lots of submarine canyons, often responsible of wave amplifications.

Focuses on Cape Verde Archipelago (Fig. 5a) and along Northwestern Africa, from Morocco to Liberia (Fig. 5b), corresponding to scenario 2 highlight these coastal amplifications that could occur after a 1843-like event. In comparison, scenario 3 MWH map (Fig. 3) shows little impact on Western Africa with a rupture's strike of $120^{\circ}$.

\subsection{Northeastern margin of South America}

Figure 6 shows MWH along the northeastern coast of South America for the second scenario, highlighting the fact that some specific places as the Maroni river mouth, between Surinam and French Guyana, or the region offshore the Delta Amacuro, seems to react particularly well to wave arriving



Figure 4. Maximum wave heights map over the bathymetric grid of the Azores archipelago (grid 2) after $12 \mathrm{~h}$ of tsunami propagation corresponding to the 1843-like scenario (no. 2).

from the north. Notice that there are noticeable tsunami wave heights despite the fact that both previous places are not located within the main energy lobe, i.e. perpendicular to the fault strike, as described by Okal (1988).

\subsection{Northwestern Atlantic coast}

This study reveals that a Caribbean tsunami, despite its location, would not spared the northwestern coasts of the Atlantic Ocean. In fact, Fig. 3 highlights that the south coasts of New Scotland and Newfoundland (Canada) and even the 


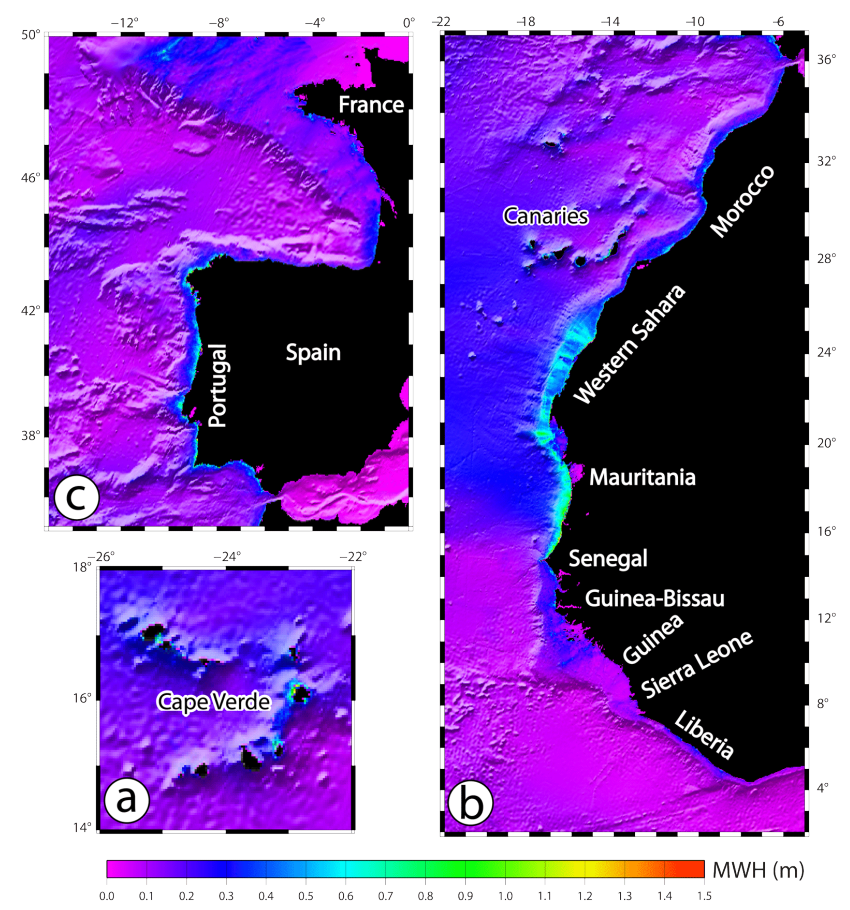

Figure 5. Maximum wave height maps after $12 \mathrm{~h}$ of tsunami propagation across the Atlantic Ocean for the 1843-like scenario (no. 2). It highlights coastal amplifications along the French and Portuguese margins (a), in the Cape Verde archipelago (b) and along the western African margin linked mainly to submarine canyon locations.

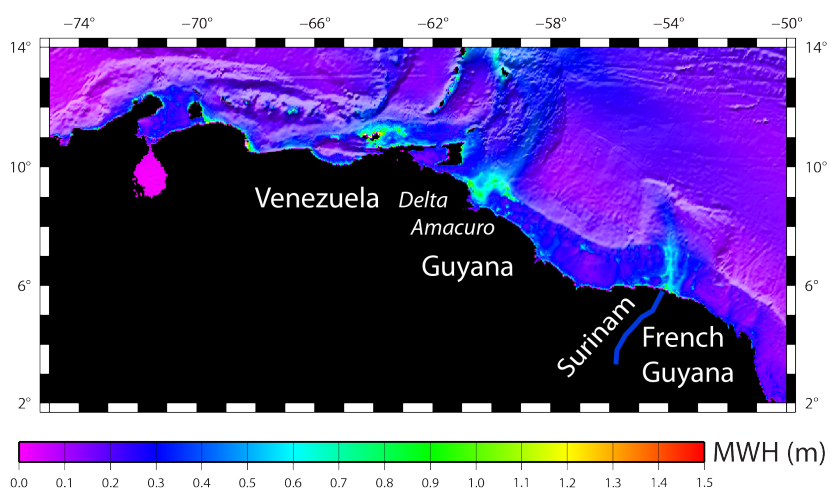

Figure 6. Maximum wave height maps after $12 \mathrm{~h}$ of tsunami propagation for the 1843-like scenario (no. 2) showing coastal amplifications in the south of the Lesser Antilles arc and along the northeastern margin of South America.

East coast of the USA could also potentially be affected by a tsunami coming from the Lesser Antilles subduction zone, regardless of rupture direction strike.

\subsection{France}

The results of the tsunami simulations for the Atlantic coast of continental France are displayed in Figs. 7-11 for the 3 scenarios.

\subsubsection{Scenario 1}

Concerning scenario 1 (the southernmost source with energy lobe directed towards Africa, shown on Fig. 5), the results reveals that the French coastline has a different response from south to north (Fig. 7a): at the latitude of the Aquitaine region, the tsunami amplification is more pronounced than at the latitude of the Vendée (from 30 to $10 \mathrm{~cm}$ ); this is probably linked to the width of the continental shelf, larger in the north and cut by a giant submarine canyon in the south (Capbreton canyon; described in Mazières et al., 2014), as noticed in Fig. 5a. In this region, local amplifications are above all observed near Arcachon's Bay (Fig. 8a).

The islands of Ré and Oléron (Fig. 9a) are exposed to a significant amplification on their ocean-ward shores, leading to MWH of about $60 \mathrm{~cm}$ at some places. By contrast, the harbour of La Rochelle and the Passage of Antioche are rather more protected (MWH of about $10 \mathrm{~cm}$ ) (Figs. 9a and 10a).

\subsubsection{Scenario 2}

Due to the source azimuth, the second scenario is expected to have the highest impact on continental France. As for scenario 1, modelling results on the French coastline display a different response off the coast of Aquitaine (MWH $60 \mathrm{~cm}$ ) than off the coast of Vendée $(\mathrm{MWH} \sim 10-30 \mathrm{~cm})$ (Figs. 7b and 8b). Similarly local coastal amplifications are still noticeable near Archachon's Bay

For this second scenario, the islands of Ré and Oléron are even more exposed to amplification on their ocean-ward shores, with $\mathrm{MWH} \sim 60 \mathrm{~cm}$ on the majority of the shore and up to $150 \mathrm{~cm}$ in Oléron (Fig. 9b), compared to the same places observed for the previous scenario (Fig. 9a).

The harbour of La Rochelle and the Passage of Antioche are more protected than the east coasts of the islands, with only significant wave heights circa $30 \mathrm{~cm}$. (Figs. 10b and 11b).

\subsubsection{Scenario 3}

Despite scenario 3 mainly directs its energy towards the North-East direction (Fig. 3), continental France shoreline is more impacted than with scenarios 1 and 2 . In this case, an off coast amplification can be seen through the whole continental slope (Fig. 7c). This amplification seems to have a periodic pattern that could be generated by the scars in the continental rise.

We note that the contrast between Aquitaine and Vendée is no more observed in this case (Figs. 7c and 8c). As in the two precedent scenarios, the islands of Ré and Oléron are still exposed to significant wave heights up to $60-80 \mathrm{~cm}$ offshore, but this time the island of Ré is struck more severely and on a longer section of the shoreline (Fig. 9c). In that case, the Passage of Antioche is also more impacted, and the nearby bays are exposed to significant wave heights, reaching $\sim 80 \mathrm{~cm}$ 


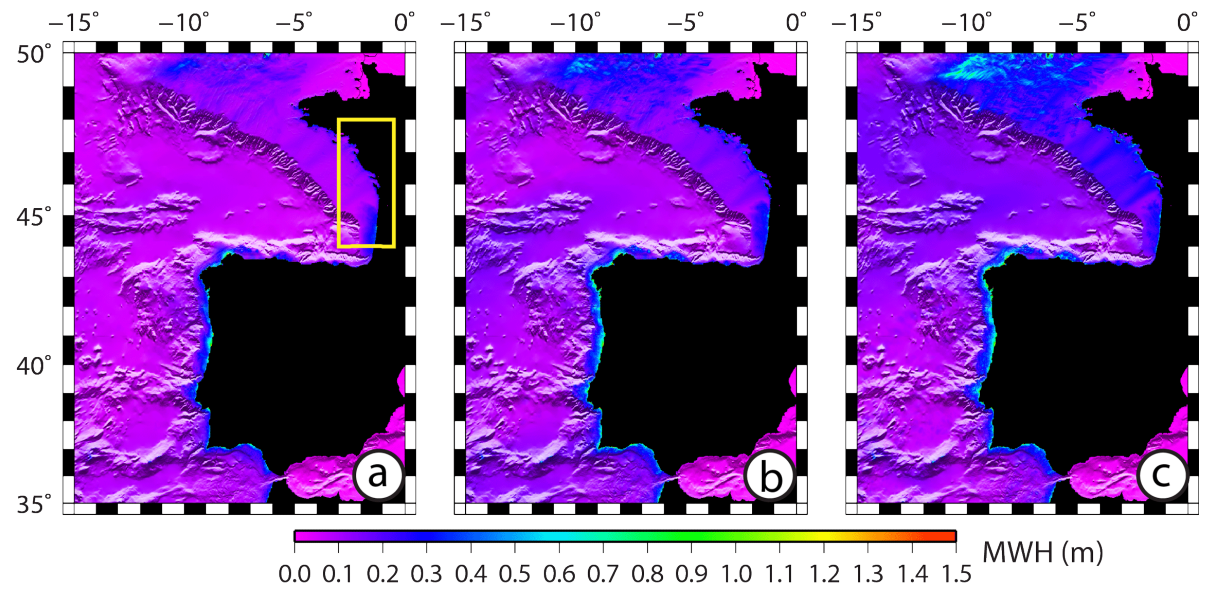

Figure 7. Maximum wave height maps obtained after $12 \mathrm{~h}$ of propagation showing coastal amplifications close to the French, Portuguese and Spanish coastline (grid 5) for the 3 scenarios. From left to right, scenarios 1 (a), 2 (b), and 3 (c). The yellow rectangle shows the position of the grid 6 .

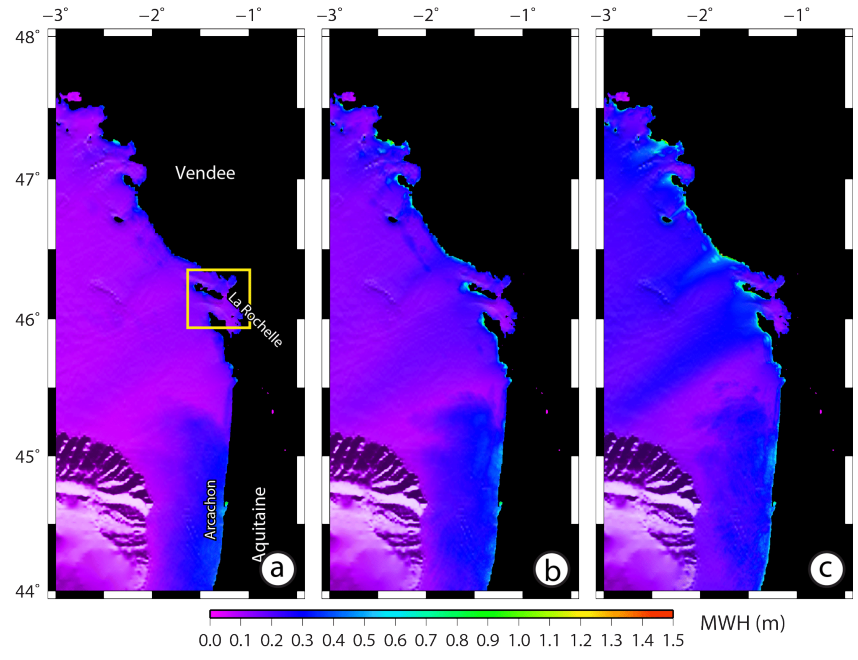

Figure 8. Maximum wave height maps obtained after $12 \mathrm{~h}$ of propagation showing coastal amplifications close to the French Atlantic coastline (grid 6) for the 3 scenarios. From left to right, scenarios 1 (a), 2 (b), and 3 (c). The yellow rectangle shows the position of the grid 7 .

locally. MWH of $60 \mathrm{~cm}$ are obtained off the southeastern village of Ré Island (Sainte-Marie-de-Ré), in la Rochelle's Minimes Yacht Harbor, in the trade port and in Godechaud Bay, south of la Rochelle (Figs. 10c and 11c).

\subsection{Portugal and Spain}

Whatever the orientation of the main tsunami energy lobe, the whole Portugal coast, Galicia (Northwestern Spain) and Western Andalousia (Southwestern Spain) are particularly impacted by tsunami wave heights of $\sim 1 \mathrm{~m}$ (Fig. 7a, b, and c).

\section{Discussion and conclusion}

Modeling results have shown that considering this specific Atlantic Ocean case, with a seismic source located along the Lesser Antilles subduction interface, the strike value, directly linked to the orientation of the main energy lobe, plays a predominant role on the potential impact of a trans-oceanic tsunami travelling across this ocean at first glance. But, after looking carefully at the results and analyzing into details the three modeled scenarios MWH along the Atlantic coastlines, and focusing on the French coastline and the harbor of la Rochelle as a high-resolution example, it seems that local amplification patterns depend more on the bathymetric conditions close to the impacted coastlines than on the rupture strike. Maximum wave heights map highlights also the fact that oceanic submarine features are able to focus the incoming front towards well-identified places: on Fig. 3, the main tsunami energy lobe obviously propagates mainly or partially towards the Azores archipelago despite the initial strike varies from 120 to $165^{\circ}$, following simply the midAtlantic ridge, which acts like a waveguide. The same way, the Kane transform and fracture zone, extending from the Bermudas to the half-way between Cape Verde and the $\mathrm{Ca}$ naries (Sharkov, 2012), also allows to focus tsunami waves onto the Mauritania and Senegal coasts and their neighborhood (Figs. 3 and 5b).

A further detailed frequency analysis of the observed amplifications in Azores or Cape Verde would help to link them to local resonance phenomenon between islands like those studied by Munger and Cheung (2008) after the 2006 Kuril tsunami reacted with Hawaii Archipelago or by Allgeyer et al. (2013) for the resonance in the Marquesas Islands. Again, sea-bottom shape showing numerous submarine canyons located along the margins are also able to focus waves energy toward specific locations aside the canyons' extremity as pro- 


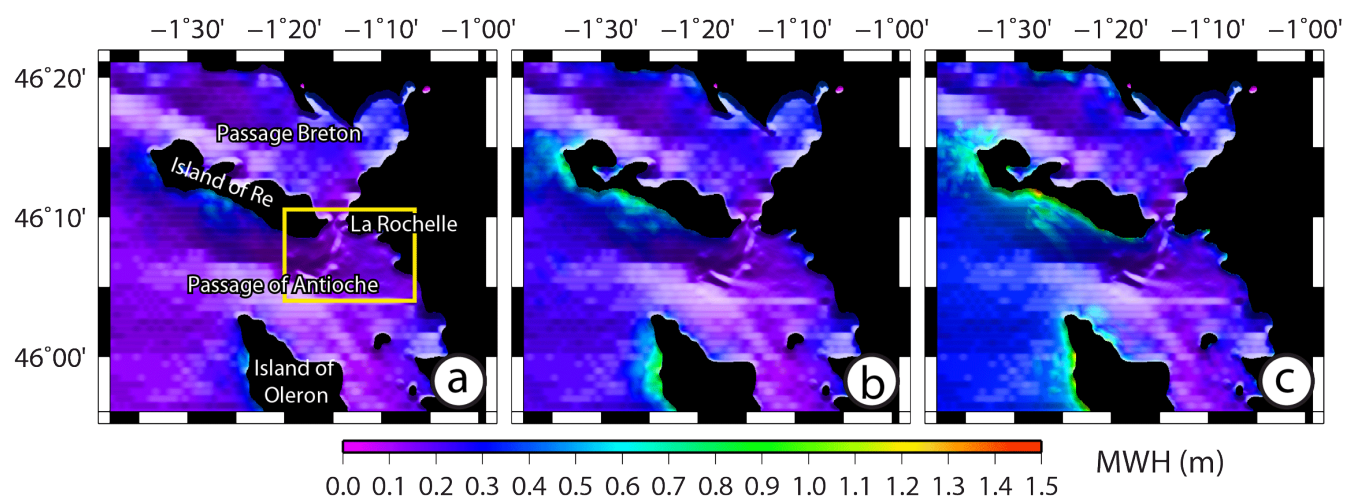

Figure 9. Maximum wave height maps obtained after $12 \mathrm{~h}$ of propagation showing coastal amplifications close to the coastal town of la Rochelle (grid 7) for the 3 scenarios. From left to right, scenarios 1 (a), 2 (b), and 3 (c). The yellow rectangle shows the position of the following grid 8 .

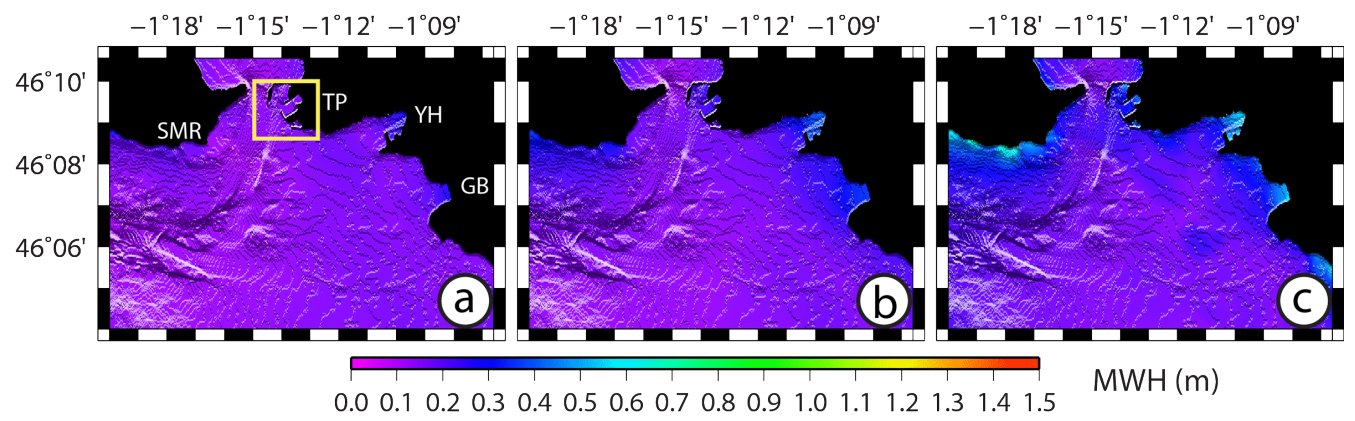

Figure 10. Maximum wave height maps obtained after $12 \mathrm{~h}$ of propagation showing coastal amplifications in the passage of Antioche (grid 8 ) for the 3 scenarios. From left to right, scenarios 1 (a), 2 (b) and 3 (c). The yellow rectangle shows the position of the following grid 9. SMR: Sainte-Marie-de-Ré, TP: trade port, YH: yacht harbor, GB: Godechaud Bay.

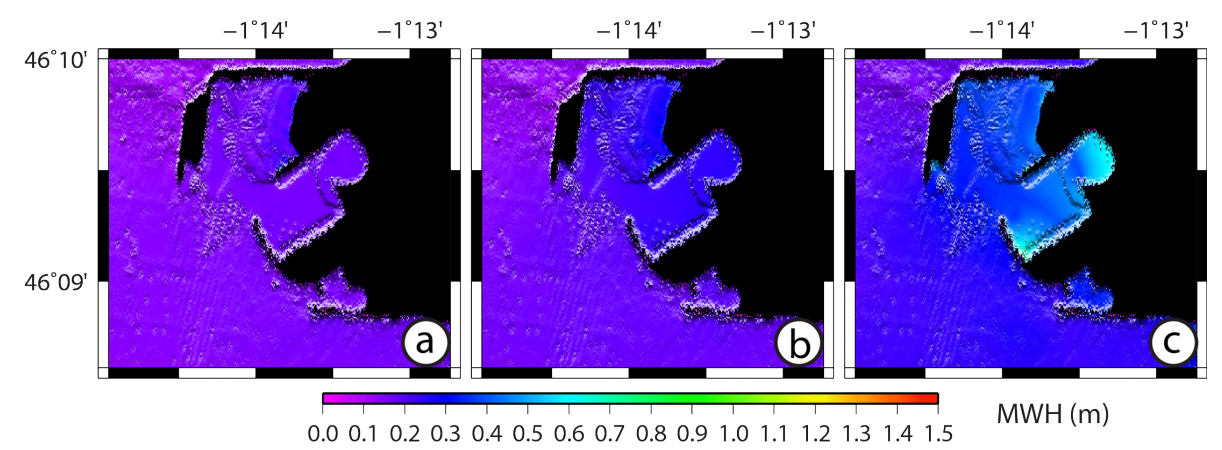

Figure 11. Maximum wave height maps for the trade port of la Rochelle (grid 9) obtained after $12 \mathrm{~h}$ of propagation for the 3 scenarios. From left to right, scenarios 1 (a), 2 (b), and 3 (c).

posed by Roger and Hébert (2008) or Ioualalen et al. (2010) for the Balearic and Atacames promontories respectively and more specifically by Divyalakshmi et al. (2011) for the southeast coast of India and Iglesias et al. (2013) onto synthetic models.

\section{Relative protection of France by the Azores}

The wave trapping by the bathymetry and the presence of the Azores Archipelago have a huge influence on modeling results along the coast of France. While the first scenario shows little MWH off France, the second and third scenarios present similar impact on those coasts, scenario 3 being finally the most restrictive. In this scenario, the maximum lobe of energy, which direction is partially due to the waveguiding 
exercised by the mid-Atlantic ridge, is directed north of the Azores Archipelago, thus leading to higher wave heights in the entrance of the Channel and western coast of France than scenario 2 (Figs. 3 and 7), for which the main energy lobe directly strikes the Azores.

Along the Armorican margin (offshore la Rochelle), and moreover in scenario 3 , a focusing of wave heights can be observed on the modeling results. One of those focuses presents its maximum near Oléron and Ré, thus explaining the higher MWH observed on the port of la Rochelle and its surrounding. These focuses are likely induced by a Bay of Biscay continental slope's Fresnel coefficient created by the slope's canyons, in addition to a possible resonance due to the margin width.

It is important to finish this discussion notifying that the $M_{\mathrm{w}} \sim 8.4$ magnitude value used in this study of a potential megathrust earthquake in the Lesser Antilles could be far exceeded in this subduction zone as demonstrated recently by the $M_{\mathrm{w}}=9.12011$ Tohoku earthquake. In fact, this catastrophic earthquake occurred in a region where the maximum known or estimated magnitude based on the historical knowledge and used for disaster plans was set to 8.0 (Stein and Okal, 2011): the 11 March 2011 event was then 30 times more powerful in terms of energy release, thus largely underestimated as indicated by Thanassoulas et al. (2012) or Kagan and Jackson (2013), amongst others, who concluded their studies pointing at the fact that a more important magnitude should have been considered in hazard plans. As indicated by McCaffrey (2008) following the 2004 Indian Ocean event, the ignorance of the return period for megathrust earthquakes of $M \sim 9$, which is the case for the Caribbean region, should not lead to an underestimation of the rupture potential of subduction zones. Thus the author estimates a megathrust earthquake recurrence time of about 1600 years for the Antilles subduction zone with a mean value of estimated magnitude minus observed magnitude $\sim 3.2$ for post-1900 events only, close to the 3.5 value for Chile, and $\sim 1.8$ for post-1700 events, leading to a maximum predicted value of $M_{\mathrm{w}} \sim 9.3$. The recent re-evaluation of the 1843 earthquake from 7.5 (maximum value considered in McCaffrey's study) to 8.5 would imply a potential $M_{\mathrm{w}} \sim 10.3$ earthquake for the Antilles subduction zone, value not considered as impossible by Kagan and Jackson (2013).

Finally, this study of various scenarios able to generate large transoceanic tsunamis in the NE Atlantic Ocean are worth being studied in the frame of the establishment of effective international warning systems, on the Caribbean side (von Hillebrandt-Andrade, 2013), as well as the European side (Baptista et al., 2011). Specifically, the possibility to have teletsunamis from one basin to another should not be discarded since in the Atlantic Ocean, two main regional warning systems must exchange information and warning messages. Historical events like the 1755 (Portugal) and 1843 (Lesser Antilles) earthquakes must be better understood to achieve these goals.
Acknowledgements. This project has been funded by the INTERREG IV TSUNAHOULE European project and by the PIA TANDEM French project. The authors would like to thank Sébastien Allgeyer for providing the bathymetric grids for the French coastline. The figures have been partly prepared using Generic Mapping Tools software from Paul Wessel.

Edited by: S. Lorito

Reviewed by: E. Geist and one anonymous referee

\section{References}

Allgeyer, S., Daubord, C., Hébert, H., Loevenbruck, A., Schindelé, F., and Madariaga, R.: Could a 1755-like tsunami reach the French Atlantic coastline? Constraints from twentieth century observations and numerical modeling, Pure Appl. Geophys., 170, 1415-1431, 2012.

Allgeyer, S., Hébert, H., and Madariaga, R.: Modelling the tsunami free oscillations in the Marquesas (French Polynesia), Geophys. J. Int., 193, 1447-1459, doi:10.1093/gji/ggt064, 2013.

Baptista, M. A. and Miranda, J. M.: Revision of the Portuguese catalog of tsunamis, Nat. Hazards Earth Syst. Sci., 9, 25-42, doi:10.5194/nhess-9-25-2009, 2009.

Baptista, M. A., Omira, R., Matias, L., Miranda, J. M., Annunziato, A., Carrilho, F., and Kaabouben, F.: On the need for a tsunami warning system in the North East Atlantic Area (Gulf of Cadiz), in: The tsunami threat - Research and Technology, edited by: Mörner, N.-A., InTech, 1-17, doi:10.5772/14068, 2011.

Barkan, R. and ten Brink, U.: Tsunami simulations of the 1867 Virgin Island earthquake: constraints on epicenter location and fault parameters, B. Seismol. Soc. Am., 100, 995-1009, 2010.

Barkan, R., ten Brink, U. S., and Lin, J.: Far field tsunami simulations of the 1755 Lisbon earthquake: Implications for tsunami hazard to the U.S. East Coast and the Caribbean, Mar. Geol., 264, 109-122, 2009.

Beauducel, F. and Feuillet, N.: The great 1843 earthquake in the Lesser Antilles Arc, AGU Fall Meeting, 3-7 December 2012, abstract T41A-2558, 2012.

Berry, M. V.: Focused tsunami waves, Proc. R. Soc. A, 463, 30553071, 2007.

Bilek, S. L. and Lay, T.: Rigidity variations with depth along interpolate megathrust faults in subduction zones, Nature, 400, 443446, 1999.

Blaser, L., Krüger, F., Ohrnberger, M., and Scherbaum, F.: Scaling relations of earthquake source parameters estimates with special focus on subduction environment, B. Seismol. Soc. Am., 100, 2914-2926, 2010.

Courant, R., Friedrichs, K., and Lewy, H.: Über die partiellen Differenzengleichungen der mathematischen Physik, Mathematische Annalen, 100, 32-74, 1928 (in German).

DeMets, C., Jansma, P. E., Mattioli, G. S., Dixon, T. H., Farina, F., Bilham, R., Calais, E., and Mann, P.: GPS geodetic constraints on Caribbean-North America plate motion, Geophys. Res. Lett., 27, 437-440, 2000.

Divyalakshmi, K. S., Rammohan, V., and Ramana Murthy, M. V.: Modification of tsunami wave by submarine canyon: case study of multiple canyons at south east coast of India, Marine Geodesy, 34, 2-15, 2011. 
Driscoll, N. W., Weissel, J. K., and Goff, J. A.: Potential for largescale submarine slope failure and tsunami generation along the U.S. mid-Atlantic coast, Geology, 28, 407-410, 2000.

Feuillet, N., Beauducel, F., and Tapponnier, P.: Tectonic context of moderate to large historical earthquakes in the Lesser Antilles and mechanical coupling with volcanoes, J. Geophys. Res., 116, B10308, doi:10.1029/2011JB008443, 2011a.

Feuillet, N., Beauducel, F., Jacques, E., Tapponnier, P., Delouis, B., Bazin, S., Vallée, M., and King, G. C. P.: The Mw =6.3, November 21, 2004, Les Saintes earthquake (Guadeloupe): tectonic setting, slip model and static stress changes, J. Geophys. Res., 116, B10301, doi:10.1029/2011JB008310, 2011b.

Fine, I. V., Rabinovich, A. B., Bornhold, B. D., Thomson, R. E., and Kulikov, E. A.: The Grand Banks landslide-generated tsunami of November 18, 1929: preliminary analysis and numerical modeling, Mar. Geol., 215, 45-57, 2005.

Grilli, S. T., Dubosq, S., Pophet, N., Pérignon, Y., Kirby, J. T., and Shi, F.: Numerical simulation and first-order hazard analysis of large co-seismic tsunamis generated in the Puerto Rico trench: near-field impact on the North shore of Puerto Rico and far-field impact on the US East Coast, Nat. Hazards Earth Syst. Sci., 10, 2109-2125, doi:10.5194/nhess-10-2109-2010, 2010.

Guibourg, S., Heinrich, P., and Roche, R.: Numerical modeling of the 1997 Chilean tsunami. Impact on French Polynesia, Geophys. Res. Lett., 24, 775-778, 1997.

Gusiakov, V. K. and Mercado, A.: Historical tsunami database for the Atlantic, 60 B.C.-2000 A.D.: Implication for risk assessment, EGS XXVII General Assembly, Nice, 21-26 April, abstract no. 3986, 2002.

Hayes, G. P., McNamara, D. E., Seidman, L., and Roger, J.: Quantifying potential earthquake and tsunami hazard in the Lesser Antilles subduction zone of the Caribbean Region, Geophys. J. Int., 195, 510-521, doi:10.1093/gji/ggt385, 2013.

Hanks, T. C. and Kanamori, H.: A moment magnitude scale, J. Geophys. Res., 84, 2348-2350, 1979.

Hildebrand, A., Marques, F. O., Catalao, J., Catita, C. M. S., and Costa, A. C. G.: Large-scale active slump of the southeastern flank of Pico Island, Azores, Geology, 40, 939-942 , doi:10.1130/G33303.1, 2012.

Iglesias, O., Lastras, G., Souto, C., Canals, M., and Costa, S.: Tsunami propagation and impact: the role of submarine canyons, EGU General Assembly 2013, 7-12 April 2013, Vienna, Austria, EGU2013-5417, 2013.

Ioualalen, M., Ratzov, G., Collot, J.-Y., and Sanclemente, E.: The tsunami signature on a submerged promontory: the case study of the Atacames Promontory, Ecuador, Geophys. J. Int., 184, 680688, doi:10.1111/j.1365-246X.2010.04878.x, 2010.

Kagan, Y. Y. and Jackson, D. D.: Tohoku earthquake: a surprise?, B. Seismol. Soc. Am., 103, 1181-1194, 2013.

Kodaira, S., Nakanishi, A., Park, J.-O., Ito, A., Tsuru, T., and Kaneda, Y.: Cyclic ridge subduction at an inter-plate locked zone off central Japan, Geophys. Res. Lett., 30, 1339, doi:10.1029/2002GL016595, 2003.

Lander, J. F., Whiteside, L. S., and Lockridge, P. A.: A brief history of tsunamis in the Caribbean Sea, Science of Tsunami Hazards, 20, 57-94, 2002.

Le Friant, A., Heinrich, P., and Boudon, G.: Field survey and numerical simulation of the 21 November 2004 tsunami at Les
Saintes (Lesser Antilles), Geophys. Res. Lett., 35, L12308, doi:10.1029/2008GL034051, 2008.

Mazières, A., Gillet, H., Castelle, B., Mulder, T., Guyot, C., Garlan, T., and Mallet, C.: High-resolution morphobathymetric analysis and evolution of Capbreton submarine canyon head (Southeast Bay of Biscay-French Atlantic coast) over the last decade using descriptive and numerical modeling, Mar. Geol., 351, 1-12, 2014.

McCaffrey, R.: Global frequency of magnitude 9 earthquakes, Geology, 36, 263-266, doi:10.1130/G24402A.1, 2008.

McCann, W. R. and Sykes, L. R.: Subduction of aseismic ridges beneath the Caribbean Plate: Implications for the tectonics and seismic potential of the northeastern Caribbean, J. Geophys. Res., 89, 4493-4519, 1984.

McCann, W. R., Dewey, J. W., Murphy, A. J., and Harding, S. T.: A large normal-fault earthquake in the overriding wedge of the Lesser Antilles subduction zone: the earthquake of 8 October 1974, B. Seismol. Soc. Am., 72, 2267-2283, 1982.

Mercado, A. and McCann, W.: Numerical simulation of the 1918 Puerto Rico tsunami, Nat. Hazards, 18, 57-76, 1998.

Müller, R. D. and Landgrebe, T. C. W.: The link between great earthquakes and the subduction of oceanic fracture zones, Solid Earth, 3, 447-465, doi:10.5194/se-3-447-2012, 2012.

Munger, S. and Cheung K. F.: Resonance in Hawaii waters from the 2006 Kuril Islands tsunami, Geophys. Res. Lett., 35, L07605, doi:10.1029/2007GL032843, 2008.

Murotani, S., Satake, K., and Fujii, Y.: Scaling relations of seismic moment, rupture area, average slip, and asperity size for $M \sim$ 9 subduction-zone earthquakes, Geophys. Res. Lett., 40, 50705074, 2013.

Murty, T. S., Nirupama, N., Nistor, I., and Rao, A. D.: Why the Atlantic generally cannot generate transoceanic tsunamis?, ISET Journal of Earthquake Technology, Technical Note, 42, 227-236, 2005.

NGDC (National Geophysical Data Center, NGDC/WDS): Global historical tsunami database, Boulder, CO, USA, available at: http://www.ngdc.noaa.gov/hazard/tsu_db.shtml, last access: 15 May 2014, 2013.

Okada, Y.: Surface deformation due to shear and tensile faults in a half-space, B. Seismol. Soc. Am., 75, 1135-1154, 1985.

Okal, E. A.: Seismic parameters controlling far-field tsunami amplitudes: a review, Nat. Hazards, 1, 67-96, 1988.

Roger, J. and Hébert, H.: The 1856 Djijelli (Algeria) earthquake and tsunami: source parameters and implications for tsunami hazard in the Balearic Islands, Nat. Hazards Earth Syst. Sci., 8, 721-731, doi:10.5194/nhess-8-721-2008, 2008.

Roger, J., Allgeyer, S., Hébert, H., Baptista, M. A., Loevenbruck, A., and Schindelé, F.: The 1755 Lisbon tsunami in Guadeloupe Archipelago: source sensitivity and investigation of resonance effects, The Open Oceanography Journal, 4, 58-70, 2010a.

Roger, J., Baptista, M. A., Sahal, A., Allgeyer, S., and Hébert, H.: The transoceanic 1755 Lisbon tsunami in the Martinique. Pure and Applied Geophysics, in: Proceedings of the International Tsunami Symposium, Novosibirsk, Russia, July 2009, doi:10.1007/s00024-010-0216-8, 2010b.

Roger, J., Baptista, M. A., Mosher, D., Hébert, H., and Sahal, A.: Tsunami impact on Newfoundland, Canada, due to far-field generated tsunamis. Implications on hazard assessment, in: Proceedings of the 9th U.S. National and 10th Canadian Conference 
on Earthquake Engineering, 25-29 July 2010, Toronto, Canada, n. $1837,2010 \mathrm{c}$.

Roger, J., Hébert, H., Ruegg, J.-C., and Briole, P.: The El Asnam October 10th, 1980 inland earthquake: a new hypothesis of tsunami generation, Geophys. J. Int., 185, 1135-1146, 2011.

Roger, J., Dudon, B., and Zahibo, N.: Tsunami hazard assessment of Guadeloupe Island (F.W.I.) related to a megathrust rupture on the Lesser Antilles subduction interface, Nat. Hazards Earth Syst. Sci., 13, 1169-1183, doi:10.5194/nhess-13-1169-2013, 2013.

Ruffman, A. and Hann, V.: The Newfoundland tsunami of November 18, 1929: an examination of the twenty-eight deaths of the "south coast disaster", Newfoundland and Labrador Studies, 21, 1719-1726, 2006.

Satake, K.: Effects of bathymetry on tsunami propagation: application of ray tracing to tsunamis, Pure Appl. Geophys., 126, 27-36, 1988.

Sharkov, E. V.: Cyclic development of axial parts of slow-spreading ridges: evidence from Sierra Leone Area, the Mid-Atlantic ridge, 5-7 ${ }^{\circ} \mathrm{N}$, in: Tectonics - Recent Advances, Earth and Planetary Sciences, edited by: Sharkov, E., ISBN: 9789535106753, 2012.

Stein, S. and Okal, E. A.: The size of the 2011 Tohoku earthquake need not have been a surprise, EOS T. Am. Geophys. Un., 92, 227-228, 2011.
Strasser, F. O., Arango, M. C., and Bommer, J. J.: Scaling of the source dimensions of interface and intraslab subduction-zone earthquakes with moment magnitude, Seismological Research Letters, 81, 941-950, 2010.

Tappin, D. R.: Mass transport events and their tsunami hazard, in: Submarine Mass Movements and their Consequences, edited by: Mosher, D. C., Shipp, C., Moscardelli, L., Chaytor, J., Baxter, C., Lee, H., and Urgeles, R., Advances in Natural and Technological Hazards Research, 28, 667-684, 2010.

Thanassoulas, C., Klentos, V., and Verveniotis, G.: Was the magnitude $(\mathrm{M}=9.0 \mathrm{R})$ of the mega-earthquake of Japan (11th of March, 2011) predictable? An analysis based on the lithospheric seismic energy flow model (LSEFM), arXiv:1204.1662, 2012.

Twichell, D. C., Chaytor, J. D., ten Brink, U. S., and Buczkowski, B.: Morphology of late Quaternary submarine landslides along the U.S. Atlantic continental margin, Mar. Geol., 264, 4-15, 2009.

von Hillebrandt-Andrade, C.: Minimizing Caribbean Tsunami Risk, Science, 341, 6149, 966-968, doi:10.1126/science.1238943, 2013.

Ward, S. N. and Day, S.: CumbreVieja Volcano - Potential collapse and tsunami at La Palma, Canary Islands, Geophys. Res. Lett., 28, 3397-3400, 2001.

Zahibo, N., Pelinovsky, E., Yalciner, A. C., Kurkin, A., Koselkov, A., and Zaitsev, A.: The 1867 Virgin Island Tsunami, Nat. Hazards Earth Syst. Sci., 3, 367-376, doi:10.5194/nhess-3-3672003, 2003. 